\title{
Rzekoma różnica między zaimkami celtyckimi a polskimi
}

Słow a kluc ze: połączenia przyimków z zaimkami w językach celtyckich i w polszczyźnie, nieregularny rozwój fonetyczny spowodowany frekwencją, etymologia słowa jemioła, wymowa nauka

Ostatnio ukazał się interesujący artykuł Piotra Stalmaszczyka (2006: 157-171) poświęcony „przyimkom zaimkowym” w językach celtyckich. Czytamy w nim, że

jedną z charakterystycznych cech morfologii współczesnych języków celtyckich jest występowanie form stanowiących połączenie przyimka i zaimka osobowego. W terminologii angielskiej formy te znane sa jako inflected albo conjugated prepositions, a także prepositional pronouns, pronominal prepositions i suffixed pronouns [...] Doyle i Gussmann [...] w polskim podręczniku do nauki języka irlandzkiego posługują się terminem zaimki przyimkowe, ale jednocześnie zwracają uwage, że „równie dobrze można by je nazywać przyimkami zaimkowymi” [...] W swoim opracowaniu języków celtyckich Bednarczuk [...] wprowadza jeszcze inny termin, a mianowicie prepozycje odmienne. Natomiast w niniejszym artykule stosowana jest nazwa 'przyimki zaimkowe', która wydaje się najlepiej opisywać charakterystyczne właściwości omawianej formy [...].

W językach celtyckich szereg najczęstszych przyimków ('przy', 'do', 'na', 'ponad', 'u', 'w', 'z' itd.) może łączyć się w jeden wyraz z zaimkami i przybierać 
odrębną formę osobową podlegającą odmianie przez osobę i liczbę, a w trzeciej osobie liczby pojedynczej również przez rodzaj.

Jako przykład P. Stalmaszczyk podaje połączenia irlandzkiego przyimka ag 'przy' z zaimkami: agam 'przy mnie', agat 'przy tobie', aige 'przy nim', aici 'przy niej', againn 'przy nas', agaibh 'przy was', acu 'przy nich'. A oto, jak się przedstawiają połączenia irlandzkiego przyimka ar 'na' z zaimkami: orm 'na mnie', ort 'na tobie', air 'na nim', uirthi 'na niej', orainn 'na nas', oraibh 'na was', orthu 'na nich'. Z kolei dowiadujemy się, że

jak słusznie zauważają Doyle i Gussmann [...], omawiane zjawisko nie jest zupełnie obce językowi polskiemu, gdzie pojawiają się, choć marginalnie, formy typu: patrzyła nań, pisała doń, odeszła odeń, cierpiała przezeń itp. Można tu wspomnieć także formy hiszpańskie conmigo 'ze mną' i contigo ' $\mathrm{z}$ tobą'. W obydwu językach jednakże występowanie tych form jest bardzo ograniczone: do trzeciej osoby rodz. m. w języku polskim i do przyimka con ' $z$ ' w pierwszej i drugiej osobie liczby pojedynczej w języku hiszpańskim. W przeciwieństwie do języka polskiego czy hiszpańskiego celtyckie formy posiadają regularne paradygmaty i występują powszechnie.

Pragnę to zagadnienie rozpatrzyć z perspektywy koncepcji nieregularnego rozwoju fonetycznego spowodowanego frekwencją. Moim zdaniem, we wszystkich językach forma wyrazów zależy od trzech podstawowych czynników, nie tylko od regularnego rozwoju fonetycznego i rozwoju analogicznego, ale także od tego, co nazywam nieregularnym rozwojem fonetycznym spowodowanym frekwencją. W moim przekonaniu bardzo często używane grupy wyrazowe, wyrazy i morfemy nieraz doznają nieregularnych redukcji, np. niegdyś bardzo często używane wyrażenie wasza miłość skróciło się do waść, słowo podobno skróciło się do pono, a prasłowiański morfem bezokolicznika *-ti najpierw prawidłowo przekształcił się w stpol. -ci, a potem -ci nieregularnie skróciło się do -ć, por. stpol. (umrze)-ci, ale dzisiejsze (umrze)-ć. Temu nieregularnemu rozwojowi poświęciłem trzy monografie (Mańczak 1969, 1977 i 1987) oraz mnóstwo artykułów.

Nieregularny rozwój fonetyczny spowodowany frekwencją przejawia się w najprzeróżniejszych postaciach, m.in. polega on na zrastaniu się grup wyrazowych w pojedyncze słowa. Np. przed udaniem się na spoczynek życzymy innym ludziom dobrej nocy. Na skutek tego, że czynimy to niemal każde- 
go dnia, grupa dwuwyrazowa dobra noc zrosła się w jedno słowo dobranoc. W grupie dwuwyrazowej dobra noc były dwa akcenty oraz możliwa była pauza między oboma słowami, natomiast w dobranoc jest tylko jeden akcent i brak pauzy. Do dziś obok zrostu dobranoc istnieje grupa wyrazowa dobra noc, ale spotyka się ją być może tysiące razy rzadziej niż słowo dobranoc.

I w tym momencie docieramy do sedna sprawy. Zrastanie się grup wyrazowych złożonych z przyimków i zaimków osobowych w pojedyncze słowa zachodzi w polszczyźnie na równie wielką skalę jak w językach celtyckich. Chodzi tylko o to, żebyśmy sobie uświadomili, że nasza pisownia połączeń przyimków z zaimkami, wzorowana na językach obcych, nie odzwierciedla wymowy. Chodzi o to, żebyśmy zechcieli zaobserwować, gdzie pada akcent, a wówczas zauważymy, że połączenia przyimków z zaimkami są wymawiane jak pojedyncze słowa z normalnym akcentem na przedostatniej sylabie:

*'namnie, *na'tobie, *'nanim, *'nanas, *'nawas, *'nanich;

*'umnie, *u'ciebie, *u'niego, *'unas, *'uwas, *'unich;

*be'zemnie, *bez'ciebie, *bez'niego, *'beznas, *'bezwas, *'beznich;

*o'demnie, *od'ciebie, *od'niego, *'odnas, *'odwas, *'odnich;

*po'demna, *pod'toba, *'podnim, *pod'nami, *pod'wami, *pod'nimi;

*'zamna, *za'tobq, *'zanim, *za'nami, *za'wami, *za'nimi;

*na'demna, *nad'toba, *'nadnim, *nad'nami, *nad'wami, *nad'nimi;

*'przymnie, *przy'tobie, *'przynim, *'przy nas, *'przywas, *'przynich;

*'kumnie, *ku'tobie, *ku'niemu, *'kunam, *'kuwam, *'kunim;

*'domnie, *do'ciebie, *do'niego, *'donas, *'dowas, *'donich.

Natomiast przy połączeniach przyimków z rzeczownikami do zrostów w zasadzie nie dochodzi, np. 'na "mchu, 'u "psa, 'bez "tchu, 'od "krwi, 'pod"las, 'za "dom, 'nad "pniem, 'przy "dnie, 'ku "psu, 'do "bzu. Dzieje się tak dlatego, że średnia częstość użycia połączeń przyimków z rzeczownikami jest niższa od średniej frekwencji połączeń przyimków z zaimkami. Jednak od ogólnej zasady, że połączenia przyimków z zaimkami zrastają się, a połączenia przyimków z rzeczownikami nie zrastają się, istnieją wyjątki. Z jednej strony, zrastają się najczęściej używane grupy przyimek + rzeczownik, np. 'Pan "Bóg > 'Pan Bóg, 'na "dót > 'na dót, 'Wielka "Noc > Wiel' kanoc, 'za "maż > 'za mąz, 'na "dwór > 'na dwór, 'spode "tba > spo'de tba, 'Biaty "Stok > Bia"tystok, 'o"bok $>$ 'obok. Z drugiej zaś strony, rzadziej używane połączenia przyimków z za- 
imkami nie zrastają się: 'ponad "mnq, 'poza "nim, 'zamiast "niej, 'wśród "nich, 'prócz "mnie.

Przy okazji warto podkreślić doniosłość koncepcji nieregularnego rozwoju fonetycznego spowodowanego frekwencją, który nie tylko zachodzi we wszystkich językach świata, ale ponadto w obrębie poszczególnych języków przejawia się w najrozmaitszy sposób. Oto dwa przykłady. W swym słowniku etymologicznym W. Boryś s.v. jemioła pisze, że

zmienność nagłosu wyrazu (*emela/*jbmela, a zwłaszcza mająca duży zasięg postać *omela, nie dająca się w takim przypadku objaśnić) nie przemawia za dopatrywaniem się tu nazwy wykonawcy czynności (z przyr. *-ela) od psł. czas. *ęti, *jbmo 'wziąć, chwycić, schwytać, złapać, ująć' [...] z pierwotnym znaczeniem 'ta, co chwyta, łapie', chociaż właściwości rośliny, z której lep był używany do chwytania ptaków, uzasadniałyby takie objaśnienie.

$\mathrm{Z}$ faktu, że jeden $<$ edinъ, jedlina, derywat od $* e d l b<$ pie. $* e d h l-$, jeleń $<$ pie. *elen-, jelito $<*$ elito, jesień $<$ pie. *esen-, jesiotr $<*$ esetrb, jest $<$ pie. $*$ esti, jeszcze < pie. *edsk" ${ }^{u}$, jezioro < pie. *eg'hero-, jeż< pie. *eg'hio-, wynika, że regularnym kontynuantem pie. *e- jest je-, a w psł. *jbmo, zestawianym z łac. emo, ${ }^{*}$ j jest rezultatem nieregularnego rozwoju fonetycznego spowodowanego frekwencją. Oczywiście dziwić nie może, że w nazwie jemioły, znacznie rzadziej używanej od czasownika jać, przetrwał regularny wokalizm nagłosowy. Tak więc nie widzę powodu do kwestionowania poglądu, że w nazwie jemioły tkwi pie. *em-.

A oto drugi przykład. Miliony Polaków wymawiają słowo nauka jako dwusylabowe, tzn. nau-ka, czyli nauka, i ja osobiście nie widzę w tym nic zdrożnego (Mańczak 2005), jednak specjaliści od poprawności językowej mój artykuł przemilczeli (a zmowa milczenia to potężna broń) i idąc w ślady Doroszewskiego, nadal w sposób mniej lub bardziej stanowczy zalecają wymowę na-u-ka. Przede wszystkim należy podkreślić, że wymowa nauk jest czymś izolowanym, ale jest tym samym, czym w gwarach bardzo rozpowszechniona wymowa chatupa jako chaupa czy dziewucha jako dzieucha lub dzioucha. Rozwój na-u-ka > nauka uwarunkowany jest częstym użyciem, o czym się można przekonać, zaglądając do słownika Kurcz i innych (1990), według którego to słownika frekwencja wchodzących w grę wyrazów przedstawia się następująco: nauczanie 18, nauczyciel 71, nauczycielka 9, 
nauczycielski 15, nauczycielstwo 5, nauczyć 11, nauczyć się 20, ale nauka 193, naukowiec 28, naukowo 5, naukowo-badawczy 9, naukowo-techniczny 10, naukowy 146. Średnia częstość użycia słów zawierających na-ucz-wynosi 21 , natomiast średnia frekwencja wyrazów zawierających nauk- -65 , co dowodzi, że wymowa nauk - powstała na skutek częstego użycia.

W trójkącie samogłoskowym samogłoska $i$ zajmuje położenie podobne do położenia samogłoski $u$ i dlatego paralelnie do spowodowanego frekwencją rozwoju $u>\underline{u}$ obserwujemy również częstością użycia spowodowany rozwój $i>j$. Zazwyczaj $i$ po samogłosce się zachowuje, por. przyimek, zaimek, zaimponować, zaimprowizować, zainicjować, zainkasować, zainteresować, zaiste, zaistnieć, uiścić, wyizolować, doigrać się, poigrać, czy fakt, że w słowniku pod redakcją Doroszewskiego jest 126 czasowników na -oić typu doić. Jednak wyjątek pod tym względem stanowią derywaty od dwu bardzo często używanych czasowników, a mianowicie iść i imać się: najść, zajść, obejść, nadejść, odejść, podejść, wejść, zejść, rozejść się, wzejść, przejść, odnajdywać itd., zajmować, obejmować, przejmować, odejmować, ujmować, pojmować itd. czy sejm, rozejm, ujma. Redukcja $i$ do $j$ trafia się także w nazwach geograficznych, por. kraina, ale Krajna, choina, ale Chojny, Chojnice. W języku ogólnopolskim kraina używane jest bez porównania częściej od Krajna i podobnie jest z choina w stosunku do Chojny, Chojnice, nie można jednak zapominać o tym, że w języku mieszkańców Krajny czy Chojnic sytuacja przedstawia się odwrotnie. Słowo ruina wymawiane jest nie tylko ru-i-na, ale i ruina, a poza tym istnieje tylko rujnować. W często używanym słowie chrześcijanin nieregularny rozwój fonetyczny spowodowany frekwencją przejawił się w zaniku $i$. Że co do tego nie może być wattpliwości, najlepiej o tym świadczy akcentuacja gen. plur. 'chrześcijan, nikt przecież nie mówi *chrześ' cijan. A czyż redukcja chrześcijanin do [chrześćjanin] nie przypomina redukcji dziewucha do dzieucha, dzioucha?

Obok nieregularnego rozwoju fonetycznego spowodowanego frekwencja istnieje inny, od dawna znany nieprawidłowy rozwój fonetyczny, na który się składają asymilacje, dysymilacje, metatezy, haplologie, zmiany spowodowane ekspresywnością czy hiperpoprawnością. Otóż zmiany te mają to do siebie, że w różnych językach zachodzą w najprzeróżniejszych słowach. Np. pol. zmierzch (z ch zamiast $k$ ) wykazuje nieregularną zmianę spowodowaną hiperpoprawnością, ale wątpliwe jest, czy w jakimś innym języku indoeuropejskim wyraz o tym znaczeniu uległ również zmianie spowodowanej hi- 
perpoprawnością. W pol. pokrzywa zaszła metateza i znowu możliwe jest, że mało jest języków na świecie, w których by w słowie o tym znaczeniu doszło do metatezy. Tymczasem nieregularne zmiany fonetyczne spowodowane frekwencją charakteryzują się tym, że w różnych językach nieraz przebiegają paralelnie, co się thumaczy faktem, że najczęściej używane wyrazy są wszędzie mniej więcej te same. Np. czasownik oznaczający mówienie w wielu językach wykazuje nieregularne redukcje, por. pol. mówić < motwić, dial. pada < powiada, pedzial < powiedziat, stpol. pry < prawi, ros. govorit, które się $\mathrm{w}$ gwarach skraca do gryt $>$ gyt, fr. parler i wł. parlare < łac. parabolare, łac. ajo $<*$ agiō, ang. speak z nieregularnym zanikiem $r$, które przetrwało w niem. sprechen, czy ang. says, said z nieprawidłową monoftongizacją dyftongu, który się zachował w rzadziej używanym lays, laid.

W związku z tym warto zwrócić uwage na to, że obok pol. dial. chaupa nieregularnie zredukowane chalpa pojawia się w gwarach czeskich i rosyjskich (w Karelii). Także kontynuanty łac. casa 'dom' w językach romańskich wykazują niekiedy nieregularne redukcje, por. fr. chez, wł. dial. ca, sthiszp. en cas czy retoromańskie akamia 'u mnie w domu'. Hol. thuis 'w domu' powstało ze skrócenia tehuis. Szwedzki przyimek hos jest nieregularnie zredukowaną postacią rzeczownika hūs 'dom'. Wreszcie nie od rzeczy będzie wspomnieć o tym, że we wszystkich językach słowiańskich występujące doma wywodzi się od loc. sg. *domōu, która to forma regularnie przeszła w domu, a nieregularnie (poprzez stadium *domō) skróciła się do doma. Nieregularne jest też zaświadczone u Homera $d \bar{o}<* d \bar{o} m$.

Pol. dzieucha, dzioucha mają paralele w innych językach. Niem. Jungfer 'dziewica' powstało ze skrócenia juncvrouwe. Podobnie hol. juffer powstało z jonkvrouw. Niem. Mädchen 'dziewczyna' jest zredukowaną postacią Mägdchen. W średnio-wysoko-niemieckim magetîn, magedîn skracało się do meitîtn, meidîn. Hol. meisje 'dziewczyna' ostatecznie wywodzi się od meiskijn. Podobnie ang. maid 'dziewczyna' jest nieregularnie skróconą postacią maiden. Ang. wench 'dziewucha' powstało na skutek nieregularnej redukcji wenchel. Rum. fată 'dziewczyna' skracane bywa do fă. W słowniku pod redakcją Trubaczowa jest wzmianka o tym, że w gwarach rosyjskich obok devuška trafia się deuška.

Nie przychodzi mi na myśl żaden język, w którym by słowo 'nauka' doznało nieregularnej redukcji. Natomiast $\mathrm{w}$ związku z redukcją $i$ do $j \mathrm{w}$ czasownikach typu pójść, odejść itp. bardzo łatwo przytoczyć przykłady na to, 
że wyraz znaczący 'iść' w różnych językach doznał nieregularnego rozwoju fonetycznego spowodowanego frekwencją, por. łac. ambulare, z którego powstało fr. aller, wł. andare, hiszp. andar, prow. ana czy retoromańskie la, ma, na (Mańczak 1974 i 1975). Również nieregularnie skrócone jest niem. gehen czy ang. go (Mańczak 1987a).

Pol. Krajna ma też paralele w innych językach, por. ang. country (z nieregularną monoftongizacją dyftongu), rum. țară < łac. terra czy słoweń. dežela 'kraj' z nieregularnym zanikiem $r$, które przetrwało w država 'państwo'. $\mathrm{Z}$ pol. chrześcijanin (z nieregularnym zanikiem $i$ ) kojarzy się fakt, że w rosyjskim obok christianin 'chrześcijanin' istnieje krestbjanin 'chłop', przy czym forma zredukowana jest używana bez porównania częściej od formy pełnej.

Elementarną zasadą pracy naukowej jest to, żeby badanych zjawisk nie rozpatrywać w izolacji, ale żeby je rozpatrywać na możliwie jak najszerszym tle. Przede mną różni ludzie zabierali głos w sprawie wymowy nauka, ale wszyscy oni rozpatrywali tę wymowę samą w sobie, nie dostrzegali żadnego związku między tą wymową a innymi zjawiskami (chciałoby się powtórzyć za poetą: takie widzi świata koło, jakie...). Ja pierwszy usiłowałem rozpatrzyć wymowę nauka na szerszym tle, co mnie doprowadziło do wniosku, że ponieważ nauka za naszych czasów odgrywa bez porównania większą rolę niż w przeszłości, o nauce mówi się dziś znacznie częściej niż niegdyś i dlatego słowo nauka doznało nieregularnej redukcji, skracając się do naukka. Oby specjaliści od poprawności językowej zechcieli wreszcie przerwać zmowę milczenia wokół mego poglądu i podjęli ze mną dyskusję, jeśli uważają mój pogląd za błędny.

\section{Bibliografia}

Kurcz I., Lewicki A., Sambor J., Szafran K., Woronczak J., 1990, Stownik frekwencyjny polszczyzny współczesnej, Kraków: Instytut Języka Polskiego PAN.

MAŃCZAK W., 1969, Le développement phonétique des langues romanes et la fréquence, Kraków: Uniwersytet Jagielloński.

MAŃCZAK W., 1974, Une étymologie romane controversée: aller, andar, etc., Revue roumaine de linguistique 19, s. 89-101.

MAŃCZAK W., 1975, Étymologie de fr. aller, esp. andar, etc. et calcul des probabilités, Revue roumaine de linguistique 20, s. 735-739. 
MAŃCZAK W., 1977, Słowiańska fonetyka historyczna a frekwencja, Kraków: Uniwersytet Jagielloński.

MAŃCZAK W., 1987, Frequenzbedingter unregelmäßiger Lautwandel in den germanischen Sprachen, Wrocław: Ossolineum.

MAŃCZAK W., 1987a, Etymologie von gehen und stehen, Kwartalnik Neofilologiczny 34 , s. 3-10.

Mańczak W., 2005, Wymowa słowa nauka, Poradnik Językowy, z. 3, s. 3-7.

Stalmaszczyk P., 2006, Przyimki zaimkowe i konstrukcje posesywne w nowożytnych językach celtyckich, Biuletyn Polskiego Towarzystwa Językoznawczego 62, s. $157-171$.

\section{Différence prétendue entre les pronoms celtiques et les pronoms polonais (rés u mé)}

Dans les langues celtiques, le groupe préposition + pronom personnel se soude en un seul mot, cf. irlandais orm 'sur moi', ort 'sur toi', air 'sur lui', uirthi 'sur elle', etc. Le but du présent article est d'attirer l'attention sur le fait que, contrairement à ce qu'on affirme, la situation est semblable en polonais si, faisant abstraction de la graphie, on considère la prononciation. En polonais, on écrit na mnie 'sur moi', na tobie 'sur toi', na nim 'sur lui', etc., mais on prononce *'namnie, *na 'tobie, *'nanim, etc. c'est-àdire que le groupe préposition + pronom personnel se soude en un seul mot, accentué toujours sur la syllabe pénultième. L'auteur explique cette évolution, aussi bien dans les langues celtiques qu'en polonais, par ce qu'il appelle développement phonétique irrégulier dû à la fréquence d'emploi. 